\title{
Application of Swertia Chirayita (Roxb. ex Fleming) Karst in Wheat Flour to Design Health Food
}

\author{
ISHWAR SUBEDI ${ }^{1 * 2}$ AND TIKA BAHADUR KARKI ${ }^{2}$ \\ ${ }^{1}$ Department of Food Technology and Quality Control, Babarmahal, Kathmandu, Nepal \\ ${ }^{2}$ Department of Biotechnology, Kathmandu University, Dhulikhel, Kavre, Nepal
}

Swertia Chirayita often known as Chiraito is a highly traded medicinal plant of Nepal. Its use in food industries is still under research. Application of the medicinal herb in bread prepared from wheat flour (550 types, 431 um particle sized with moisture 12.5\%) was assessed to evaluate sensory and physiochemical qualities. The antioxidant activity of the Chiraito was found to be $62 \%$ at $500 \mu \mathrm{g} / \mathrm{ml}$ and $15 \%$ at $100 \mu \mathrm{g} / \mathrm{ml}$ by radical scavenging method which shows Chiraito as the most significant antioxidants potential. Likewise, antibacterial activity of the herb extract also showed significantly inhibitory to selected pathogenic microorganism. Finding its functional properties, Chiraito powder (669 $\mu$ m particle sized) with 1.0 $\%, 0.10 \%, 0.00 \%$ and $0.01 \%$ respectively were added in wheat flour to make four different type of bread and carried out sensory evaluation using 9-points (Hedonic Rating Test). The data were statistically analyzed using SPSS for Analysis of Variance (ANOVA) at 5\% level of significance. The overall quality of the finished products also showed that Chiraito, as herb extract didn't affect physico-chemical properties of the product which was measured in terms of dough yield, bread volume, elasticity, acid degree, water content, crumb porosity, texture, smell and taste. Overall acceptability showed that bread (Sample D) with $0.010 \%$ was superior and liked the most. Since no entrance of Chiraito herb in modern food industries yet, the research would support production and commercialization of innovative functional health food globally.

Keywords: Antioxidant, Bread, Chiraito, Inhibition, Wheat flour

\section{Introduction}

Bread is a nutritional, culinary, social and environmental mess and one of the mankind's important discoveries, possibly ranking alongside the discovery of fire and the invention of the wheel. Bread has played a key role in the development of mankind and is a principle source of nutrition. Historically, it has contributed to language social structuring and spiritual imagery (Cauvain and Young, 2006). Recently Nepal earthquake has affected Nepalese livelihood and thousands of people have been killed and injured. It was the worst natural disaster to strike Nepal. In this situation, Agriculture being one of the main sectors of Nepal supposed to play significant role to support and build new Nepal. Sustainable utilization of Agro byproducts and Medicinal herb plants has been thought to minimize nutritional problems for economic development. In this context, medicinal native plants such as bitter herbs, Chiraito as selective herbal plant, can play vital role as functional food for healing practices. It ranks high in terms of medicinal importance and drug value among the local Nepalese folklore disorders (Phoboo, S. 2012). Its usefulness is also being utilized by Ayurveda and Yunani medicinal practices. Its use can be a possible attempt to minimize the existing illegal trade from himalayan region. Minimization of its loss is being sought hereby inventing and developing innovative functional health food products incorporating in cereal flour. Oral communication among local people mentioned that the herb has antioxidant and antimicrobial properties which is herey researched and healthy functional food is designed by incorporating in wheat flour for therapeutic use. So it definitely may convey positive impact to entrepreneurs and consumers at their lifestyle (food habit) because of its health benefit bioactive component presence. Awareness and Scale up of market through Cooperative partnership with academician, processors, health workers and consumers activists may play vital role for sustainability.

\footnotetext{
*Corresponding Author: ishwar.subedi@gmail.com
} 


\section{Materials and Methods}

\section{Materials}

Refined wheat flour (maida) used for bread preparation was obtained from Kathmndu Maida Mills (KMM) Balaju, Kathmandu, whereas Chiraito was collected from Rasuwa district at the Central zone of Nepal.The plant was taken to National Herbarium Laboratory under the Department of Plant Rsource (DoPR), Godawari, Lalitpur for plant identification. The senior botanist Mr. Binod Basnet, Chief of laboratory, identified it as Swertia Chirayita (Roxb. ex Fleming) karst. The fresh plant was taken and then dried, pressed and grinded to make powder. Other ingredients like sugar, salt, shortening (Medalia), Gluten (Vital), yeast (Victoria Instant Dry Baker's Yeast), improver (Tower), Calcium propionate, Lecithin as emulsifier (Stampfli, L and Nersten, B. 2000) and water were calculated and blended at mixture (EBPM-20L, Guangzhou South star Machine Facilities Co. Ltd. China) to make smooth dough. The dough was fermented and baked in oven (Digital Rotary Rack Oven "Ebro 68" (Guangzhou South star Machine Facilities Co. Ltd. China) at $180^{\circ} \mathrm{C}$ for 35 minutes followed by quality assessment. The samples were packed after cooling at room temperature in food grade polypylene bags for quality assessmment at Central Food Research Laboratory (CFRL), Kathmandu.

\section{Methods}

\section{Phyto-Chemical analysis of Chiraito}

Phyto-chemicals screening of the sample was carried out according to the methods of (Asthana, RK; Sharma NK. And Kulshrestha, DK; 1991). The different plant parts (Root, Leaves and Stem) were mixed with 1:1:1 ratio and its extracts obtained from Cold methanol (laboratory grade) were screened for Alkaloids, Sterols, Terpenes, Tannins, Coumarin, Saponin, Glycosides and Quinones respectively.

\section{Antimicrobial screening}

The antimicrobial activity of the extract was determined by Kirby-Bauer method in agar well diffusion (Kirtikar KR and Basu B.D. 1996). The stock cultures of bacteria were revived by inoculating in broth media and grown at $37^{\circ} \mathrm{C}$ for $18 \mathrm{~h}$ in an incubator. Then agar plates of the Muller Hilton's Agar media were prepared. Each plate was inoculated by swabbing with bacterial suspension or with $18 \mathrm{~h}$ fresh culture $\left(10^{5}-10^{6}\right.$ colony forming unit "CFU"/ml), which was swabbed evenly on the surface of solid agar media by the help of cotton swab. All the plates were incubated at $37^{\circ} \mathrm{C}$ for $24 \mathrm{~h}$ and then during observation after $24 \mathrm{~h}$, the diameter of the zone of inhibition was measured in millimeter. All the equipment used like media, Petri plates, cotton swab etc., were sterilized before performing the experiments. As well as proper labeling of the petri plates were done before performing. All the determination of antibacterial activities of plant extracts were also done in triplicates. After $20 \mathrm{~min}$, wells of $6 \mathrm{~mm}$ diameter were made in solid agar medium with the help of gel puncher and filled with $50 \mu \mathrm{l}$ of various test samples of Chiraito. The positive control wells were filled with Chloramphenicol as Standard drug.

\section{Escherichia coli \\ 2. Salmonella typhi \\ 3. Citrobacter freundii \\ 4. Klebsiella pneumonia \\ 5. Staphylococcus aureus}

The test microorganisms as shown above were obtained and screened at the laboratory of the Department of Biotechnology Kathmandu University (Dhulikhel).

\section{Antioxidant activity}

Antioxidant activity was performed in Nist College, Khusibu / Kathmandu. The rate of reduction of a chemical reaction upon addition of Free radical scavenging assay using 1,1-diphenyl-2-picrylhydrazyl radical ((DPPH) Sigma-Aldrich) was used as an indicator of antioxidant properties at $517 \mathrm{~nm} .25 \mathrm{mg}$ of dry crude extracts were taken and dissolved in distilled methanol and diluted up to $50 \mathrm{ml}$. was carried out according to Von Gadow et al. 1997. From the stock solution 100 and $500 \mu \mathrm{g} / \mathrm{ml}$ was prepared. Ascorbic acid was used as a standard. $5 \mathrm{ml}$ of each solution was taken in a test tube and $1 \mathrm{ml}$ of $0.001 \mathrm{M}$ of DPPH solution was added to it. All these solutions were kept in dark for $30 \mathrm{~min}$. Also $5 \mathrm{ml}$ methanol was taken and $1 \mathrm{ml}$ of DPPH solution was added, for control $\left(\mathrm{A}_{0}\right)$ solution. At the end of incubation period the mixtures were examined for the antioxidant activity using Optima UV Visible spectrophotometer at wavelength of $517 \mathrm{~nm}$. The experiments were performed with triplicate readings. Percentage DPPH inhibition was determined using Antioxidant activity $(\%)=\frac{\mathrm{A}_{0}}{\mathrm{~A}_{1}} \times$ 100

Where, $A_{o}$ is the absorbance of Control and $A_{1}$ is the absorbance of the sample

The physico-chemical properties of flour have been shown in the Table 1. 
Table 1. Physico-chemical properties of flour

\begin{tabular}{lc}
\hline Parameters & Wheat flour \\
\hline Moisture (\%) & 10.50 \\
Ash (\%) & 0.554 \\
Sedimentation (\%) & 10.00 \\
Falling number (\%) & 349.50 \\
Gluten index (\%) & 98.35 \\
Farinograph (500 FU) & 60.50
\end{tabular}

The moisture was determined using hot air oven, the world standard method (AACC, 2000). Similarly, ash, to determine inorganic substances, was also determined using ICC standard based on 104/1. Sedimentation value that provides information on the protein quantity and quality of flour samples, its value can be in the range of 20 or less for low protein flour with weak gluten to as high as 70 or more for high protein with strong gluten (Paul, 2000). Sedimentation value of wheat and composite flour of wheat and millet were measured respectively using lactic acid solution during a standard time interval based on AACC, ICC No 116/1. The falling number was measured using the world standard alpha amylase activity test- AACC No. 56-81B, ICC No. 107/1, ISO/DIS 3093, ASBC. Gluten is the functional component of protein and determines processing characteristics of flour. It was measured using the ICC standard No 155 and 158, AACC method No 38-12, ISO 7495. Force or torque during mixing a small quantity of dough that characterizes quality and mixing behavior of tested flour was determined by Farinograph Units (FU) following ICC standard No. 115/1. It was important to measure percentage of water absorption, dough development time (DDT), dough stability (DS) and mixing tolerance index (TI). The product formulation and process control are hereby shown in the Table 2.0 and 3.0 respectively.

Table 2. Product formulation

\begin{tabular}{lllll}
\hline & \multicolumn{4}{c}{ Type of products } \\
Ingredients & $\mathrm{A}$ & $\mathrm{B}$ & Control & $\mathrm{D}$ \\
\hline Wheat (flour \%) & 100 & 100 & 100 & 100 \\
Chiraito (\%) & 1.0 & 0.1 & 0.0 & 0.01 \\
Water (\%) & 60.5 & 60.5 & 60.5 & 60.5 \\
Salt (\%) & 1.67 & 1.67 & 1.67 & 1.67 \\
Yeast & 1.33 & 1.33 & 1.33 & 1.33 \\
Sugar (\%) & 1 & 1 & 1 & 1 \\
Lecithin(\%) & 0.65 & 0.65 & 0.65 & 0.65 \\
\hline
\end{tabular}

The lab work of final product included measurement of overall physico-chemical properties such as water content, acid degree, compressibility, resilience and elasticity where as technological properties included dough yield, bread yield, bread volume yield and baking loss as shown in Table 4.0 The acid degree which is important to determine the physical state of gluten was measured by AACC (2000) method. Compressibility was measured in terms of texture using Penetrometer. The force was measured for 5 seconds and 115 seconds respectively which were monitored as read by scale on the penetrometer. The difference in force $(\Delta \mathrm{Km})$ in 115 and 5 seconds indicated the force applied to the bread crumb $\left(\Delta \mathrm{Km}=\mathrm{Km}_{115}-\mathrm{Km}_{5}\right)$. This test was measured under the AACC, (2000) method.

\section{Table 3. Process control table}

\begin{tabular}{|c|c|c|}
\hline \multirow[t]{2}{*}{ Preparations } & kneading time (Min) & 4 \\
\hline & Temp after kneading $\left({ }^{\circ} \mathrm{C}\right)$ & 35 \\
\hline \multirow[t]{2}{*}{ Primary fermentation } & Time (Min) & 15 \\
\hline & Temp $\left({ }^{\circ} \mathrm{C}\right)$ & 35 \\
\hline \multirow{4}{*}{$\begin{array}{l}\text { Secondary } \\
\text { fermentations }\end{array}$} & Time (Min) & 50 \\
\hline & $\operatorname{Temp}\left({ }^{\circ} \mathrm{C}\right)$ & 35 \\
\hline & Step 1 -Temp $\left({ }^{\circ} \mathrm{C}\right)$ & 210 \\
\hline & Time (Min) & 10 \\
\hline \multirow[t]{4}{*}{ Baking } & Step 2 -Temp $\left({ }^{\circ} \mathrm{C}\right)$ & 200 \\
\hline & Time (Min) & 10 \\
\hline & Step 3 -Temp $\left({ }^{\circ} \mathrm{C}\right)$ & 180 \\
\hline & Time (Min) & 15 \\
\hline
\end{tabular}

\section{Sensory analysis}

The results of sensory analysis were subjected for two-way ANOVA and LSD tests at 5\% level of significance among formulations were made.

The data were statistically analyzed using SPSS for Analysis of Variance (ANOVA) at 5\% level of significance. The overall quality of the finished products also showed that Chiraito, as herb extract didn't affect physico-chemical properties of the product which was measured in terms of dough yield, bread volume, elasticity, acid degree, water content, crumb porosity, texture, smell and taste. Overall acceptability showed that bread (Sample D) with $0.010 \%$ was superior.

\section{Results and Discussions}

The Chiraito sample was collected from Rasuwa district of Nepal. The Phytochemical, antimicrobial, antioxidant properties of the herb plant was analyzed. Plant extract showed the presence of phytochemicals such as basic alkaloids, coumarin, glycosides, steroids, quinones, flavonoid and terpenoids. The antibacterial activity of the 
extract showed significantly bioactive by inhibiting the growth of selected pathogenic microbial species for the test. The zone of inhibition (ZOI) shown by the extracts was comparable to the standard antibiotics. The antioxidant activity of the sample was found to be $62 \%$ at $500 \mu \mathrm{g} / \mathrm{ml}$ and $15 \%$ at $100 \mu \mathrm{g} / \mathrm{ml}$ by radical scavenging method and showed most significant antioxidants potential. Its incorporation in wheat flour to make bread and its sensory characteristic was also studied. The bread prepared using Chiraito at the rate of $0.01 \%$ was liked the most. Since Chiraito is one of the most useful medicinal herbs found in Nepal, its use in brewery is under research as hops substitute. Mangiferin, Swetiamerin and Amarogentin found in Chiraito is potential as functional supplement (Subedi, I and Kartki, T. 2018). Magniferin is named after Mangifera indica, the leaves of mango, which is reported to possess considerable hypoglycemic property due to this phytochemical (Muruganandan, S. 2005). Mangiferin has also been reported to show suppressive effects on blood lipids in diabetes (Leiro, J.M., 2003). It is reported as antiproliferative, immunodilatory, cardiotonic and diuretic properties (Andrea, A.C, 2005). Mangiferin significantly increased heart tissue phospholipids in isoproterenol induced cardio-toxic rats suggesting cardioprotective and hypolipidemic effects (Nair and Devi, 2006). The infusion of Swertia chirayita is locally used in Nepal as an antidiabetic (Oral local communication). A review of literature indicates that mangiferin seem to have several modes of actions for counteracting diabetes and its complications; directly by stimulating insulin production, enhancing glycolytic enzymes, inhibiting glucosidase and other enzymes such as maltase, sucrase, isomaltase and aldose reductase and indirectly by its antioxidant capacity, analgesic, anti-inflammatory and antiatherogenic (Muruganandan,S., 2005), cardioprotective and antihyperlipidemic properties (Nair and Devi 2006). Swertiamarin, has been reported to possess a number of pharmacological properties such as hepatoprotective and antidematogenic/anti-inflammatory, free radical scavenging and antispastic (Vaijanathappa and Badami, 2009). Swertiamarin has also been reported as a potent lipid lowering agent comparable to the clinical drug atorvastatin which may also contribute to its cardioprotective and anti-atherosclerotic role (Vaidya, H. 2009). Swertiamarin has been reported to have very low toxicity and is anti-bacterial (Sultana and Amhed, 2013). The result from this study indicates that swertiamarin and its derivatives are present in all plant parts of Chiraito and supposed to possess functional to health benefit. Amarogentin, the bitterest compound known to mankind, is known as poismerase inhibitor (Ray, S. 1996), chemopreventive and is reported to have anti-leishmanial and gastroprotective properties (Medda,S. 1999).

The overall quality of the finished products also showed that Chiraito, as herb extract doesn't affect its physicochemical properties, which has been tabulated in Table 4.

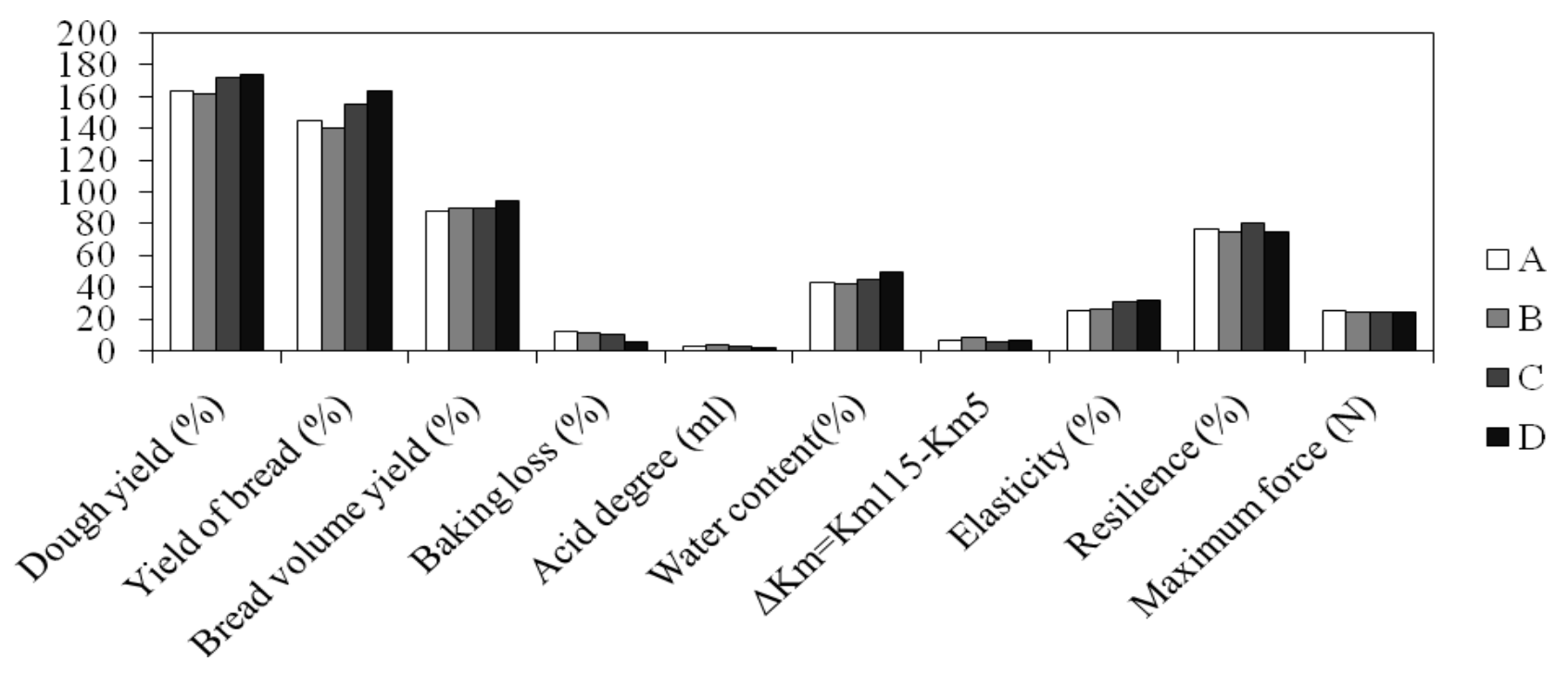

Figure 1. Overall quality of the finished product 
Table 4. Overall physico-chemical properties of the products

\begin{tabular}{lllll}
\hline & \multicolumn{4}{c}{ Samples } \\
Parameters & A & B & Control & D \\
\hline Dough yield (\%) & 164 & 162 & 172 & 174 \\
Yield of bread (\%) & 145 & 140 & 155 & 164 \\
Bread volume yield (\%) & 88.1 & 89.5 & 90 & 94.1 \\
Baking loss (\%) & 12 & 11 & 10 & 6 \\
Acid degree(ml) & 2.8 & 3.3 & 2.6 & 2.1 \\
Water content(\%) & 42.6 & 42.1 & 44.7 & 49.9 \\
$\Delta$ Km=Km115-Km & 7 & 8 & 6 & 7 \\
Elasticity (\%) & 25.5 & 26.5 & 31 & 32 \\
Resilience (\%) & 76.4 & 75 & 80.7 & 75 \\
Maximum force (N) & 25.56 & 24.05 & 24.50 & 24.4 \\
\hline
\end{tabular}

\section{Conclusions}

In order to develop the baking science in flour confection technology, application of Swertia chiraita from 0 to $1.0 \%$ in fine wheat flour $(431 \mu \mathrm{m})$ for the production of bread has been investigated. The Chiraito herb was tested to assess its antimicrobial and antioxidant property prior to application in flour confection. Then it was determined to add in wheat flour and bread was prepared. The products so prepared were subjected to sensory evaluation using 9-points (Hedonic Rating Test) and data were statistically analyzed using SPSS for Analysis of Variance (ANOVA) at 5\% level of significance. The Statistical sensory analysis (Color, Crumb, Texture, Taste, Crust and Overall acceptability) showed that bread (Sample D) product supplemented with $0.010 \%$ Chiraito powder was found to be significantly superior among all bread formulations. So it can be recommended that wheat flour has a good potential for use as a functional agent in bakery products to design health foods.

\section{References}

AACC (2000), Approved methods of the American Association of Cereal Chemists, 10th edition, The Association: St. Paul, MN.

Andrea A. C., Lyons D. E., Haile M. and Butler E. A. (2005), Ethno-archaeological Approaches to the Study of Prehistoric Agriculture in the Ethiopian Highlands. In: Vander Veen, Ed., The Exploitation of Plant Resources in
Ancient Africa. Kluwer Academic: Plenum Publishers, New York.

Asthana, RK; Sharma NK; Kulshrestha, DK; Chattarjee, SK. Oxford: Pergamon Press; (1991). Phytochemistry v. 30(3): p 1037-1039; 1991.

Cauvin S. and Young L. (2006), Baked products: Science Technology and Practices,Bake Tran, High Wycombe, Bucks, UK, Blackwell publishing, pp: 156.

Kirtikar K.R. and Basu B.D. "Antipyretic activity of six medicinal plants of India”, Indian Med Plants (1984): 3, 1664-6

Leiro J.M. (2003)“'In vitro effects of mangiferin on superoxide concentrations and expression of the inducible nitric oxide synthetase, tumour necrosis factor-alphaand transforming growth factor-beta genes". Biochem. Pharma: 65:1361-1371.

Muruganandan, S., (2005), "Effect of mangiferin on hyperglycemia and atherogenicity in streptozotocin diabetic rats". J. Ethnopharma: 97,497-501.

Medda S., Mukhopadhyay S. and Basu M.(1999) "Evaluation of the in-vivo activity and toxicity of amarogentin, an anti-leishmanial agent, in both liposomal and niosomal forms" J. Antimicrob. Chemothe: 44,791-4.

Nair P.S. and. Devi C.S.S.(2006) "Efficacy of mangiferin on serum and heart tissue lipids in rat subjected to isoproterenol induced cardio toxicity". Toxicology : 228,135-139.

Paul, M. (2000), Approved methods of American Association of Cereal Chemists, $10^{\text {th }}$ edition, adopted from methods 56-61A

Phoboo, S. (2012), Phenolic-linked biochemical rationale for the anti-diabetic properties of Swertia chirayita, Copyright (C) 2012 John Wiley \& Sons, Ltd. Phytother Res. 2013 Feb;27(2):227-35.

doi: https://www.ncbi.nlm.nih.gov/pubmed/22523004

Ray, S. (1996) "Amarogentin, a naturally occurring secoiridoid glycoside and a newly recognized inhibitor of topoisomerase I from Leishmaniadonovani" J. Nat. Pro. (1996): 59,27-29.

Stampfli L. and Nersten B. (2000), Emulsifiers in bread making, MATFORSK, Norwegian Food Research Inistitute, Osloveien 1, N- 1430 AS, Norway.

Subedi I. and Karki T, (2018), Comparison of Phytochemicals of Native Plant, Swertia Chirayita (Roxb. ex Fleming) Karst from Rasuwa District in Nepal, Open access Scientific Journal, Ecronicon, published on 17Jan, 2018, available in https://www.ecronicon.com/ecnu/pdf/ECNU-13-00418.pdf 
Subedi \& Karki: J. Food Sci. Technol. Nepal, Vol. 10 (1-6), 2018

Sultana J. and Ahmed R. (2013) "Phytochemicals Investigations of the Medicinal Plant SwertiaChirata Ham", Biochemistry and Analytical Biochemistry: Volume 2, Issue 4, 1000145 Department of Materials Sciences and Engineering, Rajshani University, Rajshani ,Bangladesh, ISSN: 2161-1009 Biochem, an open access journal

Vaidya, H., et al. (2009)"Swertiamarin: A lead from EnicostemmalittoraleBlume. for anti-hyperlipidaemic effect". Eur. J. Pharm : 617,108-112.

Vaijanathappa, J. and S. Badami (2009). "Anti edematogenic and free radical scavenging activity of swertiamarin isolated from Enicostemmaaxillare”. Plant Med : 75,12-17 